\title{
Legislators, Judges, and Professors
}

\section{Ed. by Jürgen Basedow, Holger Fleischer and Reinhard Zimmermann}

[Gesetzgeber, Richter und Professoren.]

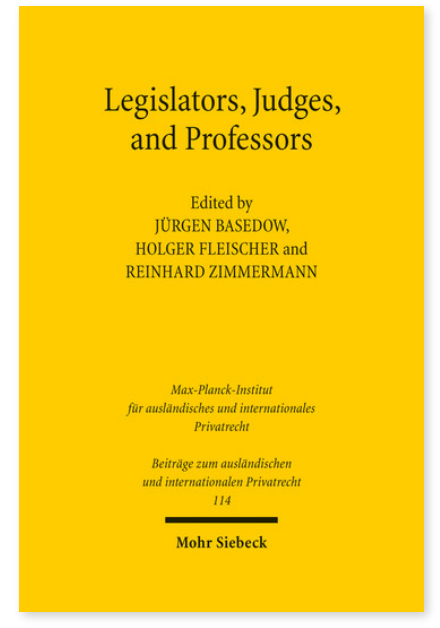

2016. XIII, 249 Seiten. BtrIPR 114

ISBN 978-3-16-154986-1

DOI 10.1628/978-3-16-154986-1

eBook PDF

ISBN 978-3-16-154985-4

Leinen $74,00 €$

\section{Veröffentlicht auf Englisch.}

Der vorliegende Band enthält die Vorträge eines Symposiums, das vom Max-Planck-Institut für ausländisches und internationales Privatrecht in Zusammenarbeit mit der Internationalen Vereinigung der juristischen Wissenschaft und der Gesellschaft für Rechtsvergleichung veranstaltet wurde. Damit werden die rechtsvergleichenden Studien zur Erforschung der juristischen Methodik fortgeführt.

Inhaltsübersicht

\section{Law-Making Today}

Yuko Nishitani: Law-Making in Japan - Başak Baysal: Law-Making in Turkish Private Law - Andrey M. Shirvindt: Reforming the Russian Civil Code. A Search for Better Law-Making

Judicial Decision-Making Today

Thomas Coendet: Judicial Decision-Making Today. The Swiss Perspective - Matthew Dyson: Judicial Decision-Making in England and Wales - Agustín Parise: Judicial Decision-Making in Latin America. Unveiling the Dynamic Role of the Argentine Supreme Court

\section{Legal Methodology Today}

Aditi Bagchi: On the Very Idea of Legal Methodology - Jean-Sébastien Borghetti: Legal Methodology and the Role of Professors in France. Professorenrecht is not a French Word! - Helen Scott: The Death of Doctrine? Private-Law Scholarship in South Africa Today

Holger Fleischer is Director at the Max Planck Institute for Comparative and International Private Law in Hamburg and Affiliate Professor at the Bucerius Law School, Hamburg.

Jürgen Basedow (1949-2023)

1997-2017 Director em. of the Max Planck Institute for Comparative and International Private Law and Professor of Law, University of Hamburg.

Reinhard Zimmermann ist Direktor am Max-Planck-Institut für ausländisches und internationales Privatrecht und Professor an der Bucerius Law School, Hamburg.

https://orcid.org/0000-0003-0348-7929

Jetzt bestellen:

https://mohrsiebeck.com/buch/legislators-judges-and-professors-9783161549861?no_cache=1 order@mohrsiebeck.com

Telefon: $+49(0) 7071-923-17$

Telefax: $+49(0) 7071-51104$ 